\title{
Gefaalde scheiding
}

\author{
Mr. T.A. Keijzeren C.C. de Kluiver*
}

Op 29 september 2015 wees het Hof Den Bosch arrest over afgeleide schade. In deze bijdrage gaan de auteurs in op de bredere casus. Eerst wordt de keuze voor de enquêteprocedure en de toepassing daarvan besproken. Vervolgens wordt het aspect van vennootschappelijke concurrentie behandeld, door vergelijking met het leerstuk van corporate opportunity. Tot slot komen het leerstuk van afgeleide schade en de daarvoor belangrijke vraag of een bestuurder de opzet heeft gehad om aandeelhouders te benadelen aan bod.

\section{Inleiding}

Op 29 september 2015 deed het Hof Den Bosch een belangwekkende uitspraak. Het arrest staat niet op zichzelf: de procederende partijen houden elkaar reeds vijf jaar juridisch bezig, hetgeen (onder andere) heeft geleid tot het faillissement van de belangrijkste werkmaatschappij en elf uitspraken van verschillende gerechtelijke instanties. ${ }^{1}$ Hoewel het een tussenuitspraak betreft, kiezen wij er toch voor deze reeds te bespreken, nu de belangrijkste lijnen waarlangs het verschil verloopt al zijn uitgetekend. Wij beperken ons daarbij niet tot de inhoud van het meest recente arrest van het hof, maar bespreken juist de bredere casus. Met hun gedragingen raken Mulix, InfoRhei en HITS aan een groot aantal leerstukken van Nederlands vennootschapsrecht. Wij zijn daarom genoodzaakt een selectie aan te brengen in de te bespreken onderwerpen. Voor degene die een meer volledig beeld nastreeft, raden wij lezing van de afzonderlijke uitspraken van harte aan.

Deze bijdrage is als volgt opgebouwd. Eerst geven wij een overzicht van de feiten en verhoudingen die ten grondslag liggen aan de onderhavige uitspraak en een weergave van die uitspraak zelf (par. 2). In paragraaf 3 plaatsen wij enkele observaties bij de eerdere processuele gang van zaken, met name wat

* Mr. T.A. Keijzer is als onderzoeker verbonden aan de Sectie Ondernemingsrecht en Financieel recht van de Erasmus School of Law te Rotterdam. C.C. de Kluiver is masterstudent aan de Universiteit Utrecht en de Universiteit van Amsterdam.

1. Rb. Breda 25 januari 2010, ECLI:NL:RBBRE:2010:BL0392; Hof Amsterdam (OK) 3 mei 2010, ECLI:NL:GHAMS:2010:BM9902, ARO 2010/82; Hof Amsterdam (OK) 20 mei 2010, ECLI:NL:GHAMS: 2010:BM9904, ARO 2010/83; Hof Amsterdam (OK) 1 november 2010, ECLI:NL:GHAMS:2010:BO8889, ARO 2010/161; Hof Amsterdam (OK) 12 januari 2011, ECLI:NL:GHAMS:2011:BP6195, ARO 2011/24; Hof Amsterdam (OK) 14 april 2011, ECLI:NL:GHAMS: 2011:BQ4818, ARO 2011/72; Hof Amsterdam (OK) 4 mei 2011, ECLI:NL:GHAMS:2011:BQ4819, ARO 2011/73; Hof Amsterdam (OK) 20 januari 2012, ECLI:NL:GHAMS:2012:BV2307, ARO 2012/16; Hof Amsterdam (OK) 13 augustus 2012, ECLI:NL:GHAMS: 2012:BX8596, ARO 2012/126; Rb. Zeeland-West-Brabant 29 januari 2014, C/02/252752/HA ZA 12-556 (ongepubliceerd); Hof Den Bosch 29 september 2015, ECLI:NL:GHSHE:2015:3780. betreft de keuze voor de enquêteprocedure en de toepassing daarvan. Daarna komt een van de belangrijkste materiële thema's van deze casus aan bod, zijnde het aspect van elkaar beconcurrerende aandeelhouders, dat wij bespreken aan de hand van het leerstuk van corporate opportunity (par. 4). Het feit dat de eerder aangewende rechtsmiddelen het faillissement van de belangrijkste werkmaatschappij niet hebben kunnen voorkomen, heeft geleid tot het instellen van een vordering wegens afgeleide schade. In paragraaf 5 gaan wij op dat leerstuk nader in. Afronding volgt in paragraaf 6.

\section{De feiten: een schets}

\subsection{Vennootschappelijke structuur}

Geïntimeerde (hierna: Horsten) is bestuurder en enig aandeelhouder van HITS Holding BV (hierna: HITS Holding), die bestuurder en enig aandeelhouder is van Horsten IT Solutions BV (hierna: HITS). Van Lakwijk, Hooghiemstra en Lips (hierna: Van Lakwijk c.s.) zijn houder van respectievelijk $37,5 \%, 25 \%$ en $37,5 \%$ van de certificaten van aandelen InfoRhei BV (hierna: InfoRhei). InfoRhei en HITS zijn bestuurder en beide voor $50 \%$ aandeelhouder van Mulix Holding BV (hierna: Mulix Holding), bestuurder en enig aandeelhouder van Mulix BV (hierna: Mulix). Mulix Holding is voorts bestuurder en aandeelhouder - eerst voor $65 \%$, later voor $100 \%$ - van Mulix Zuid-Oost Nederland BV (hierna: Mulix ZON). ${ }^{2}$ Van Lakwijk c.s. en Horsten zijn tot slot, al dan niet via een tussenhoudster, ieder voor 25\% aandeelhouder in Hillmark BV (hierna: Hillmark). Tot het vermogen van Hillmark behoren bedrijfspanden, in gebruik bij InfoRhei en Mulix. InfoRhei houdt zich bezig met het vervaardigen en implementeren van IT-producten op het gebied van human resources (HR). Voor haar werkzaamheden leende zij personeel in bij Mulix, die een onderneming dreef op het gebied van het detacheren van ICT-personeel. Namens HITS zijn de bestuurstaken bij Mulix uitgevoerd door Horsten en namens InfoRhei door Lips. Beiden ontvingen ter vergoeding een management fee van respectievelijk EUR 9400 per maand en EUR 2467,50

2. De beslommeringen van Mulix ZON blijven in deze bijdrage echter grotendeels buiten beschouwing. 
Figuur 1

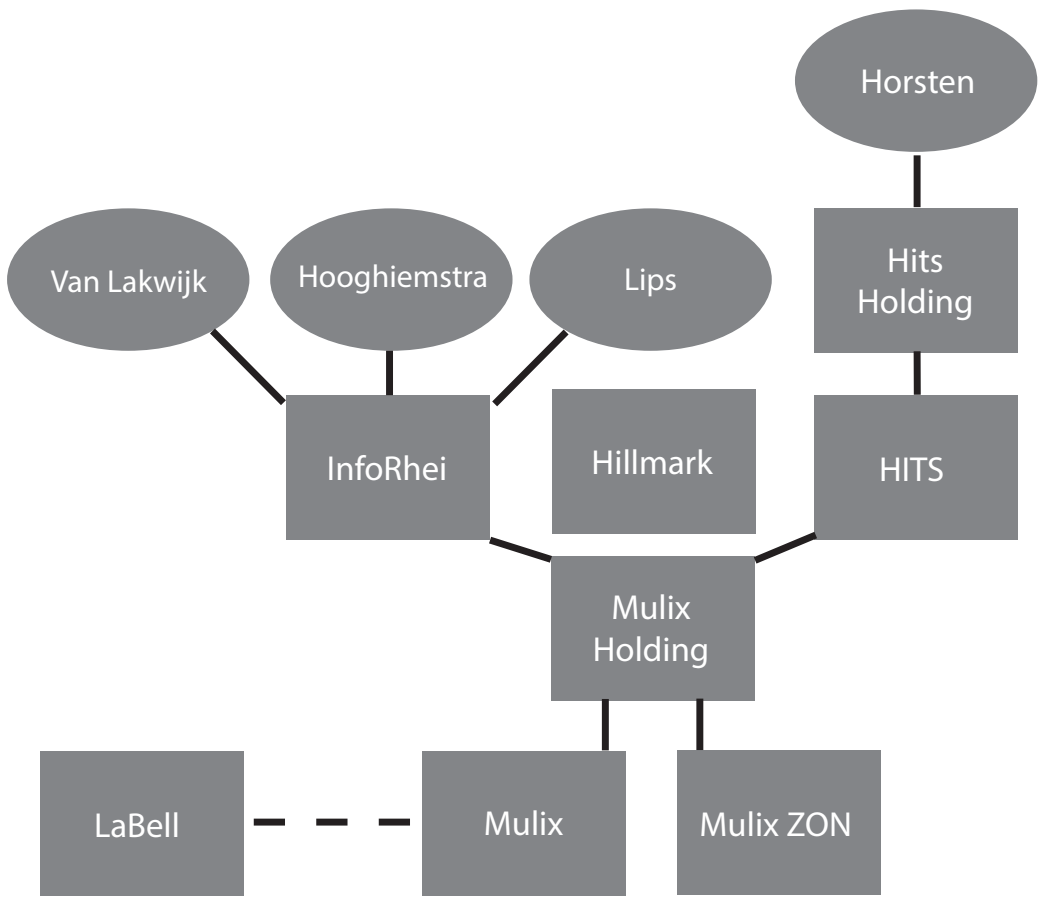

per kwartaal. ${ }^{3}$ Zie figuur 1 (ter simplificatie wordt de relatie van de verschillende aandeelhouders met Hillmark niet lineair weergegeven).

\subsection{Onderlinge geschillen}

Het lijkt een verschil van inzicht omtrent de door Horsten voorgestelde aankoop (door Hillmark) van een bedrijfspand, in november 2008, te zijn geweest dat aanleiding heeft gegeven tot de verschillende gerechtelijke procedures. In 2009 is de verhouding tussen Horsten en Van Lakwijk c.s. verder verslechterd. Op 5 mei 2009 heeft Horsten EUR 66.550,18 overgemaakt aan HITS, als (beweerdelijke) managementvergoeding over de eerste vier maanden van dat jaar. Horsten heeft vervolgens (op 6 mei) per mail (1) te kennen gegeven met terugwerkende kracht tot 2004 aanspraak te maken op een maandelijkse management fee van EUR 13.981,13 (Horsten vorderde in totaal een achterstallig bedrag van EUR 326.471,78), (2) een voorstel gedaan tot overname van de aandelen van InfoRhei in Mulix Holding (in feite uitkoop van Van Lakwijk c.s.) en (3) aangegeven te verlangen dat InfoRhei haar aandelen in Mulix aan HITS zou verpanden, tot zekerheid voor haar betalingsverplichting. Op 29 mei heeft Horsten een bedrag van EUR 150.000 overgemakt van Mulix aan HITS, omdat Horsten geen fiducie meer zou hebben in het Nederlandse bancaire systeem. Dit bedrag is op 8 juni terugbetaald. InfoRhei (en daarmee Mulix Holding) heeft met geen van de voorstellen van Horsten ingestemd. In de loop van 2009 heeft een van de grootste klanten van Mulix, zonder dat

3. Deze schets is ontleend aan Hof Den Bosch 29 september 2015, ECLI:NL:GHSHE:2015:3780, r.o. 3.1-3.5. een opzegtermijn in acht is genomen, de langdurige samenwerking beëindigd, waarna de klant rechtstreeks bediend werd door InfoRhei. Horsten heeft op 20 oktober 2009 LaBell BV (hierna: LaBell) opgericht. De resterende klanten van Mulix zijn vervolgens (deels) ondergebracht bij LaBell; LaBell heeft enige tijd als handelsnaam Mulix ICT Services gevoerd. ${ }^{4}$

\subsection{Procedure Ondernemingskamer en Hof Den Bosch} InfoRhei heeft op 28 december 2009 bij de Ondernemingskamer (hierna: OK) een enquêteverzoek ingediend, omdat zij van HITS onvoldoende informatie zou krijgen om haar bestuurstaken goed uit te kunnen voeren. Ook zou HITS weigeren bestuursvergaderingen te houden, waardoor onder meer de jaarstukken over 2008, 2009 en 2010 nog niet waren vastgesteld - de (niet-vastgestelde) jaarstukken laten overigens een winst zien van EUR 22.000 (2009) respectievelijk een verlies van EUR 506.000 (2010). Verder zou HITS, in strijd met aandeelhoudersbesluiten, geld uit Mulix wegsluizen of reserveren. Op 3 mei 2010 heeft de OK een onderzoek bevolen naar het beleid en de gang van zaken bij Mulix en Mulix Holding, nu de OK constateerde dat de verhoudingen tussen Horsten enerzijds en Van Lakwijk c.s. anderzijds ernstig waren verstoord. De OK heeft daarom achtereenvolgens een onderzoeker en een bindend adviseur benoemd om tot ontvlechting te komen, in beginsel volgens de lijn dat Horsten Van Lakwijk c.s. zou uitkopen in Mulix en dat Van Lakwijk c.s. Horsten zouden uitkopen bij Hillmark. Het is de partijen echter niet gelukt om tot ontvlechting te komen. Mulix is op 26 juli 2011 failliet verklaard, op aanvraag van twee werknemers. Op 20

4. Hof Den Bosch 29 september 2015, ECLI:NL:GHSHE:2015:3780, r.o. 3.1 sub j-r. 


\section{Maandblad}

Ondernemingsrecht

januari 2012 heeft de OK vastgesteld dat, door het treffen van voorzieningen, het verhogen (zonder instemming van Mulix Holding) van de managementvergoeding, het verduisteren van EUR 150.000 en in verband met de beperkte informatievoorziening, in onderling verband beschouwd, sprake was van wanbeleid. De OK heeft voorts geoordeeld dat, gelet op de grote onderlinge verschillen, voor Mulix Holding geen toekomst is weggelegd. De vennootschap is daarom door de OK ontbonden; het faillissement is op verzoek van de vereffenaar uitgesproken per 29 mei 2012. Voor het Hof Den Bosch vordert InfoRhei, als aandeelhouder van Mulix Holding, een vergoeding voor de door haar als aandeelhouder in Mulix Holding geleden afgeleide schade, na bij de Rechtbank Zeeland-WestBrabant ter zake nul op het rekest te hebben gekregen.

\section{Procesverloop: enkele kanttekeningen}

\subsection{Alternatieven voor de gekozen rechtsmiddelen}

De geschillenregeling (art. 2:335 e.v. van het Burgerlijk Wetboek $(B W))$ is in beginsel gericht op duurzame ontvlechting van aandeelhouders. Het karakter van de enquêteprocedure (art. 2:344 e.v. BW) is anders; zij heeft bijvoorbeeld tot doel het herstel van de gezonde verhoudingen (curatief) en het vaststellen van verantwoordelijkheid met het oog op mogelijk wanbeleid (inquisitoir). ${ }^{5}$ Formeel kan zij niet leiden tot een overdracht van aandelen. ${ }^{6}$ De onderhavige zaak lijkt derhalve op het eerste gezicht meer geschikt voor toepassing van de geschillenregeling. Eén nadeel van de geschillenregeling is echter dat zij in de regel veel tijd in beslag neemt - minimaal 48 maanden. In een enquêteprocedure kan de OK nu juist op zeer korte termijn (eventueel van dwingend recht afwijkende) onmiddellijke voorzieningen treffen. Buijn en Storm stellen dan ook dat het 'verbazing mag wekken dat er in 2010 nog steeds advocaten waren die hun cliënten meenamen op het uitgestrekte mijnenveld van de geschillenregeling. ${ }^{7}$ De wetgever heeft dit probleem onderkend, hetgeen in 2012 heeft geleid tot enige aanpassingen in de geschillenregeling. Zo is het mogelijk, anders dan voorheen, dat een tussen- of eindvonnis uitvoerbaar bij voorraad wordt verklaard. ${ }^{8}$ Desondanks lijkt voor toepassing van de vernieuwde regeling vooralsnog niet

5. HR 10 januari 1990, ECLI:NL:HR:1990:AC1234, NJ 1990/466 m.nt. Maeijer; R.M. Hermans, Het onderzoek in de enquêteprocedure, in: G. van Solinge \& M. Holtzer (red.), Geschriften vanwege de Vereniging Corporate Litigation 2002/2003, Deventer: Kluwer 2003, p. 113-173.

6. Ondanks een pleidooi van Cools en Kroeze om de enquêteprocedure aan te passen. Zie met nadere verwijzingen F. Veenstra \& P.G.F.A. Geerts, Doorbreking van impasses in de enquêteprocedure, in: B.F. Assink e.a. (red.), De toekomst van het ondernemingsrecht. Het ondernemingsrecht van de toekomst (Timmerman-bundel), Deventer: Kluwer 2015, p. 565-592. Uiteraard is wel mogelijk dat partijen ter zitting een minnelijke regeling treffen, inhoudende waardering en overdracht van aandelen. Zie daarover F.K. Buijn \& P.M. Storm, Ondernemingsrecht BV en NV in de praktijk, Deventer: Kluwer 2013, p. 1065.

7. Buijn \& Storm 2013, p. 1025-1027 en 1093.

8. Over de wijzigingen uitgebreid C.D.J. Bulten e.a., De nieuwe geschillenregeling (Preadvies van de Vereeniging 'Handelsrecht'), Deventer: Kluwer 2011. bijzonder veel interesse te bestaan. ${ }^{9}$ In de gewijzigde opzet kent de geschillenregeling nog steeds meer verplichte 'stations' dan de enquêteprocedure. ${ }^{10}$

De lange looptijd van de geschillenregeling had in het onderhavige geschil uiteindelijk geen fataal probleem behoeven te zijn. Hoewel vrij ongebruikelijk, kan uitstoting eveneens in kort geding worden gevorderd; met name bij de Rechtbank Breda - waar de uitstootvordering in het onderhavige geval aangebracht had moeten worden - bestaat daarmee ervaring. ${ }^{11}$ Een recent voorbeeld is de zaak Baremans/Muijs, waar in kort geding een uitstotingsvordering tussen twee 50/50-aandeelhouders, tevens echtelieden in scheiding, werd toegewezen. ${ }^{12}$ In die zaak waren de verhoudingen ter algemene vergadering duurzaam verstoord en dreigde de belangrijkste financier met het blokkeren van de kredietfaciliteit - hetgeen tot een faillissement zou hebben geleid - indien er geen aandelenoverdracht zou plaatsvinden. Het aldus inkleden van de uitstootvordering lag met name voor Van Lakwijk c.s. voor de hand - de algemene vergadering van InfoRhei had daar wel mee hebben moeten instemmen - nu hun in verschillende instanties minder (zware) verwijten werden gemaakt dan Horsten. ${ }^{13}$ Gelet op de situatie van Mulix Holding is een dergelijk kort geding op enig moment, maar met name vanaf eind 2009, nadat voorzienbaar was dat de verliezen over 2010 sterk zouden oplopen, niet zonder kans geweest. Het betreft dan de bijzondere en spoedeisende situatie dat de BV zonder ingrijpen voorzienbaar failleert en de besluitvorming omtrent het bereiken van een oplossing, bijvoorbeeld het aantrekken van financiering, gefrustreerd is en wordt. ${ }^{14}$ Van voor artikel 256 van het Wetboek van Burgerlijke Rechtsvordering ( $\mathrm{Rv}$ ) onoverkomelijke complexiteit hoeft onzes inziens dan ook geen sprake te zijn: het is in essentie buigen of barsten. ${ }^{15}$ Het belang van de uit te stoten aandeelhouder tot zekerheid van betaling van de koopsom was beschermd geweest - en de kans op toewijzing van de vordering derhalve vergroot - wanneer de uitstoter had

9. M.E.C. Lok \& B. Kemp, Scheiding als gevolg van gefaalde liefde, Ondernemingsrecht $2015 / 36$, par. 3.1

10. Zie kritisch over uitvoerbaarheid bij voorraad van de geschillenregeling J.H.M. Willems, Uitvoerbaar bij voorraad, verhouding met het enquêterecht, in: De nieuwe geschillenregeling (Preadvies van de Vereeniging 'Handelsrecht'), Deventer: Kluwer 2011, p. 149-175.

11. Lok \& Kemp 2015, par. 3.2.1, met nadere verwijzingen; C.D.J. Bulten \& J.H.M. Willems, Geschriften vanwege de Vereniging Corporate Litigation 2013-2014, Deventer: Kluwer 2014, par. 5.3.6.

12. Rb. Breda 23 november 2011, ECLI:NL:RBBRE:2011:BU5680, JOR 2012/37 m.nt. C.D.J. Bulten.

13. Vgl. Hof Amsterdam (OK) 3 mei 2010, ECLI:NL:GHAMS: 2010:BM9902, ARO 2010/82, r.o. 3.1-3.4 en Hof Den Bosch 29 september 2015, ECLI:NL:GHSHE:2015:3780, r.o. 3.11-3.12.

14. Uitgebreider over succesvolle voorbeelden van uitstoting in kort geding en de nadere toepassingsvoorwaarden C.D.J. Bulten, De geschillenregeling ten gronde (diss. Nijmegen), Deventer: Kluwer 2011, p. 340-351.

15. B.F. Assink \& W.J. Slagter, Compendium Ondernemingsrecht, Deventer: Kluwer 2013, p. 1321, tekenen dan ook aan dat de rechter zich in het gros van de gevallen bevoegd heeft verklaard. 
gevorderd dat ten gunste van de uitgestotene een pandrecht zou zijn gevestigd, gelijk in Baremans/Muijs het geval was. ${ }^{16}$

Met het oog op toepassing van de uitstootregeling is wel de vraag in hoeverre Horsten, zoals vereist blijkens de parlementaire toelichting op artikel 2:336 lid $1 \mathrm{BW}$, een verwijt gemaakt kan worden in zijn hoedanigheid van aandeelhouder. ${ }^{17}$ Het lijkt immers primair zijn bestuurshandelen - het voorstel tot aankoop van een (toekomstig) bedrijfspand van Mulix door Hillmark in november 2008 en de daaropvolgende discussie omtrent de verhoging van de management fee begin 2009 - te zijn geweest dat aanleiding heeft gegeven voor onenigheid. Wij wijzen er echter op dat de onvrede in de bestuurskamer overgeslagen is naar de algemene vergadering, zodat wegens een patstelling ter algemene vergadering uiteindelijk zelfs niet het faillissement van Mulix Holding door dat orgaan aangevraagd kon worden; alsdan is wel degelijk sprake van gefrustreerde besluitvorming. ${ }^{18} \mathrm{Had}$ de hoedanigheidseis in het onderhavige geval echter een onoverkomelijke horde gevormd, dan hadden partijen - maar met name InfoRhei en wederom afhankelijk van de voorkeuren van Van Lakwijk c.s. - nog een uittreedvordering kunnen instellen. ${ }^{19}$

Wij tekenen nog aan dat, indien een dergelijke uittreedvordering later had gespeeld, InfoRhei geprofiteerd zou kunnen hebben van het per 1 oktober 2012 (met onmiddellijke werking) ingevoerde artikel 2:343 lid 4 BW. Deze bepaling maakt het mogelijk dat de rechter een billijke verhoging van de waarde van de over te dragen aandelen toepast, indien aannemelijk is dat gedragingen van de gedaagde (Horsten) hebben geleid tot een vermindering van de waarde van de over te dragen aandelen en deze vermindering niet (volledig) voor rekening van eiser (InfoRhei) behoort te blijven. Dogmatisch vormt deze bepaling een uitzondering op de regel dat voor vergoeding van afgeleide schade in beginsel geen plaats is. ${ }^{20}$ Gelet op het feit dat Horsten in de ogen van zowel de OK als het Hof Den Bosch meer blaam treft dan InfoRhei, had een vordering ex artikel 2:343 lid 4 BW heel wel kunnen slagen, wellicht eerder dan een vordering wegens afgeleide schade - waarover paragraaf 5 hierna.

16. Vgl. L.L.M. Prinsen, Open normen, belang en actie bij geschillen in besloten ledenverhoudingen. 'Scheidingsmelding' in het ondernemingsrecht, Den Haag: Boom Juridische uitgevers 2013, p. 143, die spreekt van een 'meesterlijke vordering, waarmee het belang van Muijs werd geëcarteerd'.

17. Zie ter bevestiging Hof Amsterdam (OK) 27 oktober 1994 ECLI:NL:GHAMS:1994:AD2243, NJ 1996/167 (Muller/Muts). Voor een pleidooi tegen de hoedanigheidseis zie Bulten 2011, p. 61-64, met verdere verwijzingen.

18. Hof Den Bosch 29 september 2015, ECLI:NL:GHSHE:2015:3780, r.o. 3.1 sub dd.

19. Ook dat kan (conceptueel) in kort geding, hoewel nog niet succesvol toegepast. Zie Bulten 2011, p. 355-356.

20. Asser/Maeijer, Van Solinge \& Nieuwe Weme 2-II* 2009, par. 722. Voor een succesvol beroep op art. 2:343 lid 4 BW, zie Rb. Noord-Holland 9 juli 2014, ECLI:NL:RBNHO:2014:11287, JOR 2014/323 m.nt. C.D.J. Bulten.

\subsection{Rol OK en betrokkenen}

De OK heeft achtereenvolgens een onderzoeker benoemd en een bindend adviseur ${ }^{21}$ aangesteld om tot ontvlechting te komen, dit volgens de lijnen van het voorstel van Horsten. Het is hun echter niet gelukt de betrokkenen tot overeenstemming te laten komen. In reactie op de moeizame gang van zaken heeft de OK vervolgens besloten Mulix Holding te ontbinden. Dit kan op basis van artikel 2:356 sub $\mathrm{f} \mathrm{BW}$. Wel is ontbinding door de $\mathrm{OK}$ zeldzaam; het betreft een ultimum remedium pur sang, dat in eerste instantie als stok achter de deur is bedoeld. ${ }^{22}$ Dat sprake is van een zeldzaamheid geldt des te meer indien er, zoals in het onderhavige geval, geen concreet ontbindingsverzoek lag, hoewel de OK ook dan - vergelijk Zwagerman ${ }^{23}$ - geacht moet worden bevoegd te zijn tot ontbinding over te gaan.

Toch rijzen er in dit verband enkele vragen, allereerst wat betreft de motivering. Zo wordt uit de OK-beschikking van 20 januari 2012 niet duidelijk hoe Van Lakwijk c.s. en Horsten tegenover de optie van ontbinding stonden, maar vermeldt r.o. 3.14 slechts dat zij naar hun standpunt zijn gevraagd. Hoewel InfoRhei heeft aangegeven (r.o. 1.13) zich niet langer aan een overeenkomst met de bindend adviseur gebonden te achten, laat zulks de optie open dat geen van beide de ontbinding van Mulix Holding uiteindelijk heeft gewild - zie in dat verband ook de niet-ingetrokken (r.o. 1.10) verzochte voorzieningen in r.o. 1.5 sub $\mathrm{f}$, g en h. Evenmin wordt duidelijk hoe ontbinding zich verhoudt tot de belangen van werknemers - hoewel niet ondenkbaar is dat die er niet (meer) zijn - of crediteuren (art. 2:357 lid 7 BW). Gelet op de omstandigheden is het oordeel van de OK niet vreemd, maar het oogt qua motivering wat 'dun'. Ten gronde rijzen eveneens vragen. Dient de oorzaak voor het feit dat de onderzoeker er niet in is geslaagd de betrokkenen 'aan tafel te krijgen' niet (mede) te worden gezocht in het feit dat niet als onmiddellijke voorziening - bij uitstek hét kenmerk van de enquêteprocedure - is verzocht om benoeming van een bestuurder of commissaris, al dan niet in combinatie met de aanstelling van een $\mathrm{OK}$ functionaris als tijdelijk beheerder van aandelen Mulix (Holding)? Hetzelfde kan worden gezegd voor de benoeming van de bindend adviseur. ${ }^{24}$ Ondertussen kiest de OK, door te besluiten tot ontbinding, voor de gemakkelijke weg; zij is 'van het gedoe' af - maar als partijen 'strakker op de bal' hadden gezeten, was de uitkomst wellicht anders geweest.

\section{Vennootschappelijke concurrentie}

\subsection{De vergelijking met JOR 1996/54}

Horsten heeft de activiteiten van Mulix (deels) voortgezet onder de vlag van LaBell. Dit brengt de door de OK aangestel-

21. Resp. ARO 2010/83 en ARO 2011/72 (zie noot 1).

22. Y. Nethe, Ontbinding en vereffening van de rechtspersoon, Deventer: Kluwer 2013, par. 32.

23. HR 1 maart 2002, ECLI:NL:HR:2002:AD9857, NJ 2002/296 m.nt. Maeijer, JOR 2002/79 m.nt. F.J.P. van den Ingh.

24. Vgl. de procedure in Hof Amsterdam (OK) 26 juli 2011, ECLI:NL:GHAMS:2011:BT2315, JOR 2011/330 m.nt. Bulten. 


\section{Maandblad}

Ondernemingsrecht

de onderzoeker ertoe in het verslag te stellen dat de situatie zich enigszins laat vergelijken met het geval van JOR $1996 / 54 .{ }^{25}$ In die zaak had Ramp, bestuurder en aandeelhouder van Holstar BV (hierna: Holstar), een eigen onderneming opgericht en zich op dezelfde markt als Holstar - de handel in embryo's - begeven. Daarna zijn door Ramp de bancaire kredietfaciliteiten van Holstar opgezegd. Geoordeeld werd dat het een bestuurder niet aangaat om, nog voordat de samenwerking met de andere bestuurder in het verband van de vennootschap is beëindigd, concurrerende activiteiten te gaan ontwikkelen, de samenwerking abrupt te beëindigen en de activiteiten die tot dan toe in het kader van de vennootschap werden bedreven voor zichzelf en samen met anderen te gaan bedrijven. ${ }^{26}$ Alhier is echter geen sprake van nieuw te ontwikkelen, eigen concurrerende activiteiten; in plaats daarvan werd een reeds gedreven onderneming door de bestuurder aan de bijbehorende rechtspersoon (Mulix) onttrokken. Ook heeft Horsten de samenwerking met Van Lakwijk c.s. in Mulix niet volledig beëindigd; hij is immers aangebleven als bestuurder en aandeelhouder. Helemaal zuiver is de vergelijking, als aangegeven, niet.

\subsection{Corporate opportunity}

Het aspect van vennootschappelijke concurrentie kan ook in een breder verband worden bezien. In de Verenigde Staten is het leerstuk van de corporate opportunity ontwikkeld. Dit concept heeft ook toepassing gevonden in (met name lagere) Nederlandse rechtspraak. Van een definitieve doorbraak is nog geen sprake. ${ }^{27}$ Een corporate opportunity wordt wel gedefinieerd als 'een mogelijkheid die zich voor de vennootschap voordoet om een transactie aan te gaan of zakelijke activiteiten te ontplooien die passen binnen de bedrijfsuitoefening. ${ }^{28}$ Soms wordt ook vereist dat kenbaar is dat de BV bij de opportunity een redelijk belang heeft of zou kunnen hebben. De toepassingsvoorwaarden kunnen derhalve verschillen. ${ }^{29}$ Is een corporate opportunity aanwezig, dan komt zij in beginsel toe aan de vennootschap, tenzij sprake is van 'vrijgave' door de algemene vergadering. ${ }^{30}$ De bestuurder die een kans, zonder vrijgave, ten

25. Hof Amsterdam (OK) 16 maart 1995, ECLI:NL:GHAMS: 1995:AG3006, JOR 1996/54 m.nt. F.J.P. van den Ingh; Hof Den Bosch 29 september 2015, ECLI:NL:GHSHE:2015:3780, r.o. 3.1 sub y.

26. Hof Amsterdam (OK) 16 maart 1995, ECLI:NL:GHAMS: 1995:AG3006, JOR 1996/54 m.nt. F.J.P. van den Ingh, r.o. 5.1-5.6.

27. Ph.W. Schreurs \& L.A. van Driel, 'Corporate Opportunity: (nog steeds) wachten op de doorbraak', in: M. Holtzer, A.F.J.A. Leijten \& D.J. Oranje (red.), Geschriften vanwege de Vereniging Corporate Litigation 2011-2012, Deventer: Kluwer 2012. De aldaar beschreven stand van zaken is wat ons betreft niet fundamenteel veranderd. Over corporate opportunities uitgebreid A.F. Verdam, Corporate Opportunities. Over de toe-eigening door functionarissen van aan de vennootschap toebehorende business opportunities (diss. Tilburg), Zwolle: W.E.J. Tjeenk Willink 1995.

28. Verdam 1995, p. 1, in navolging van C.AE. Uniken Venema, Corporate opportunities; aspecten van loyaliteit in het kader van een onderneming naar Amerikaans en Nederlands recht, in: B. Baardman e.a., Jurist in bedrijf, Deventer: Kluwer 1980.

29. Voor een overzicht van de verschillende factoren, zie Verdam 1995, p. 42-55 en 95-116.

30. Verdam 1995, p. 143; Rb. Zwolle 30 januari 2008, ECLI:NL:RBZWO: 2008:BG0842, JOR 2009/30 m.nt. Storm en verwijzingen. behoeve van zichzelf exploiteert, kan persoonlijk aansprakelijk zijn conform artikel 2:8 en 2:9 BW. ${ }^{31}$

Hoe verhoudt het voorgaande kader zich tot de onderhavige zaak? Horsten heeft de activiteiten van Mulix in die vennootschap stopgezet (niet de samenwerking als geheel, zie par. 4.1) en voortgezet onder de vlag van LaBell, hetgeen ertoe heeft geleid dat potentiële winsten aan Mulix zijn onttrokken. Helder was ook dat Mulix een duidelijk belang had bij de activiteiten die door Horsten in de vorm van LaBell zijn voortgezet. Daarmee heeft Horsten in strijd gehandeld met artikel 2:9 BW. ${ }^{32}$ Strikt genomen valt het onderhavige geval - overhevelen van reeds bestaande bedrijfsactiviteiten - niet aan te merken als het ontnemen van een corporate opportunity. Het leerstuk veronderstelt immers een toekomstgericht element, ${ }^{33}$ dat alhier afwezig is. Te beargumenteren valt wel dat de mogelijkheid voor Mulix tot het ontplooien van zakelijke activiteiten (in casu op het gebied van ICT-detachering) zich telkens opnieuw voordoet. Wanneer men dan in gedachten houdt dat Horsten - zonder vrijgave door de algemene vergadering van Mulix - door onttrekking van de onderneming aan de rechtspersoon is aangevangen met het benutten van deze mogelijkheid voor zichzelf, buiten Mulix om, kan men het leerstuk van corporate opportunity in de omgekeerde vorm ('reverse corporate opportunity') toepassen. Tot meer kan de vergelijking van de onderhavige situatie met het leerstuk van corporate opportunity onzes inziens niet leiden. Wel makt zij duidelijk dat InfoRhei voor wat betreft de vennootschappelijke concurrentie hetzelfde verwijt gemaakt kan worden als Horsten. Reeds per 1 juni 2009 - derhalve voordat LaBell werd opgericht (namelijk in oktober 2009) - waren Mulix en InfoRhei elkaars concurrenten geworden, nadat InfoRhei was gestopt ('plotseling en zonder goede grond') met het inlenen van personeel van Mulix. ${ }^{34}$ Van vrijgave door de algemene vergadering van Mulix van de desbetreffende klant - alsdan zou InfoRhei geen blaam treffen - blijkt niet. Dat wat betreft vennootschappelijke concurrentie minder gewicht aan de gedragingen van InfoRhei wordt toegekend dan aan die van Horsten, hangt samen met het bestuurshandelen van laatstgenoemde, als vermeld in paragraaf 2.2. In die benadering wordt Horsten gezien als aanstichter van het conflict.

\section{Afgeleide schade}

\subsection{Juridisch kader}

$\mathrm{Nu}$ het uitblijven van een (juridische) oplossing heeft geleid tot het faillissement van Mulix, vordert InfoRhei voor het Hof Den Bosch een vergoeding voor de in haar hoedanigheid van aandeelhouder van Mulix Holding geleden (derhalve afgelei-

31. Storm in JOR 2009/30, die ook nader ingaat op het onderscheid tussen art. 2:8 en 2:9 BW, dat wij hier laten rusten.

32. Hof Den Bosch 29 september 2015, ECLI:NL:GHSHE:2015:3780, resp. r.o. 3.1, 3.11.5 en 3.12.

33. In de zin dat sprake is van nieuw te ontwikkelen activiteiten. Vgl. Verdam 1995, p. 103-104.

34. Hof Amsterdam (OK) 20 januari 2012, ECLI:NL:GHAMS 2012:BV2307, ARO 2012/16, r.o. 3.7. 
de) schade. Onder afgeleide schade wordt verstaan schade die een aandeelhouder lijdt door waardevermindering van zijn aandelen, wanneer en voor zover het gevolg van schade toegebracht aan de vennootschap. ${ }^{35}$ Het leerstuk heeft zich de afgelopen tijd in aanzienlijke belangstelling mogen verheugen. Zo speelde het concept van afgeleide schade een belangrijke rol in de zaak OAD/Rabo. Ook wees het Hof Arnhem-Leeuwarden recentelijk een interessant arrest over de vraag of afgeleide schade zich bij een CV kan voordoen. ${ }^{36}$ In Poot/ABP is bepaald dat, indien een derde vermogensschade aan een vennootschap toebrengt, in beginsel alleen die vennootschap gerechtigd is om schadevergoeding te vorderen. Deze regel geldt evenzeer, zo kwam in Tuin Beheer aan de orde, indien het een bestuurder is die de vennootschap schade toebrengt. ${ }^{37}$ Een aandeelhouder heeft geen recht om naast de vennootschap vergoeding van afgeleide schade te vorderen, tenzij die derde jegens de aandeelhouder een specifieke zorgvuldigheidsnorm heeft geschonden. ${ }^{38}$ Uit Tuin Beheer volgt dat van een dergelijke schending bijvoorbeeld sprake kan zijn bij opzet tot benadeling van de aandeelhouder. In opzet tot benadeling van de vennootschap ligt echter nog geen opzet tot benadeling van de aandeelhouder besloten. ${ }^{39}$

$\mathrm{Na}$ Tuin Beheer is de vraag opgekomen of, zoals Van Veen en Van Wechem in hun annotatie (zie voetnoot 38) hebben betoogd, in beginsel slechts sprake is van schending van een specifieke zorgvuldigheidsnorm jegens een aandeelhouder in geval van opzet, of dat een dergelijke schending ook in andere omstandigheden denkbaar kan zijn, en dat opzetaspect slechts een voorbeeld betreft. Met Assink zijn wij van mening dat niet duidelijk is waarop Van Veen en Van Wechem hun standpunt baseren. ${ }^{40}$ Schild concludeert dat de Hoge Raad geen nadere bedoelingen heeft gehad met zijn opmerking, door de formulering van het arrest te bezien tegen de achtergrond van de formulering van het cassatiemiddel. ${ }^{41} \mathrm{Wij}$ concluderen dat het aspect van opzet geen vereiste is en sluiten ons derhalve aan bij Kroeze, die stelt dat het aspect van opzet slechts één mogelijkheid betreft, en dat eveneens sprake van schending van een specifieke zorgvuldigheidsnorm kan zijn wanneer het een contractuele afspraak met één of meer aandeelhouders betreft. ${ }^{42}$

35. M.J. Kroeze, Afgeleide schade en afgeleide actie (diss. Utrecht), Deventer: Kluwer 2004, p. 17-18.

36. Resp. Rb. Midden-Nederland 4 november 2015, ECLI:NL:RBMNE: 2015:7748 (OAD/Rabo) en Hof Arnhem-Leeuwarden 6 oktober 2015, ECLI:NL:GHARL:2015:7491, JOR 2015/329 m.nt. Blanco Fernández.

37. HR 16 februari 2007, ECLI:NL:HR:2007:AZ0419, NJ 2007/256 m.nt Maeijer (Tuin Beheer). Dat een bestuurder ook als derde in de zin van Poot/ABP dient te gelden, kwam reeds aan de orde in HR 13 oktober 2000, ECLI:NL:HR:2000:AA7491, NJ 2000/699 m.nt. Maeijer (Heino Krause), waarin het geen BV of NV maar een coöperatie betrof.

38. HR 2 december 1994, ECLI:NL:HR:1994:ZC1564, NJ 1995/288 m.nt. Maeijer (Poot/ABP), r.o. 3.4.3.

39. HR 16 februari 2007, ECLI:NL:HR:2007:AZ0419, JOR 2007/112 m.nt. Van Veen en Van Wechem (Tuin Beheer).

40. Assink in zijn annotatie onder HR 2 november 2007, ECLI:NL:HR: 2007:BB3671, JOR 2007/302 (Kessock/SFT Bank), par. 4.

41. A.J.P. Schild, Afgeleide schade?, Bb 2008/30.

42. Kroeze in zijn annotatie onder HR 2 november 2007, ECLI:NL:HR: 2007:BB3671, Ondernemingsrecht 2008/13 (Kessock/SFT Bank).
Wij kunnen ons ook vinden in de redenering van Assink, die betoogt dat schending van een specifieke zorgvuldigheidsverplichting aangenomen kan worden ter zake van een specifieke statutaire bepaling die beoogt een aandeelhouder te beschermen, of indien sprake is van gerechtvaardigde verwachtingen. Van belang is daarbij of de geleden schade als definitief beschouwd kan worden. ${ }^{43}$

\subsection{Arrest Hof Den Bosch}

In de onderhavige situatie lijkt het wellicht bijzonder dat het überhaupt tot een procedure over afgeleide schade komt. In verband met (mogelijk) paulianeus handelen door Horsten als bestuurder van Mulix heeft eerstgenoemde immers met de curator een vaststellingsovereenkomst gesloten. Daarin is bepaald dat aan Horsten tegen betaling van EUR 50.000 finale kwijting wordt verleend voor het 'leeghalen' van Mulix, en dat reeds ingestelde vorderingen ex artikel 42 en 43 van de Faillissementswet zijn ingetrokken. De geleden schade moet in zoverre geacht worden te zijn gecompenseerd. Andere gedragingen van Horsten, zoals het omleiden van winsten naar LaBell, worden door de vaststellingsovereenkomst echter niet bestreken. ${ }^{44}$ In zoverre kan InfoRhei wel degelijk een vordering wegens afgeleide schade instellen.

De Rechtbank Zeeland-West-Brabant heeft de vorderingen van InfoRhei in eerste aanleg afgewezen. De rechtbank oordeelde dat InfoRhei niet aan haar stelplicht had voldaan. Uit de gedragingen van Horsten volgde volgens de rechtbank niet dat hij de opzet had om InfoRhei als aandeelhouder te benadelen; zulks kon althans niet worden afgeleid uit de (vermeende) afwezigheid van een andere reden voor oprichting van LaBell dan dat InfoRhei en HITS niet langer hun winsten zouden hoeven te delen. ${ }^{45}$ Horsten had bovendien aangevoerd dat hij aldus beoogde de onderneming en werknemers van Mulix (hun baan) te (laten) behouden. ${ }^{46}$ Een aanbod van InfoRhei tot nader getuigenbewijs inzake de bij Horsten aanwezige opzet werd door de rechtbank gepasseerd. Gelet op de centrale positie die het opzetaspect inneemt en de regels omtrent het bewijsaanbod van artikel $166 \mathrm{Rv}$ had de rechtbank op dit vlak onzes inziens ook anders kunnen oordelen.

43. Zie voor een volledig overzicht van relevante omstandigheden Assink \& Slagter 2013, par. 14; voor het geval waarin werd geoordeeld dat wanprestatie/schending van gerechtvaardigde verwachting overtreding van een specifieke zorgvuldigheidsnorm oplevert (Kessock/SFT Bank), is overigens maar de vraag of sprake was van afgeleide schade.

44. Hof Den Bosch 29 september 2015, ECLI:NL:GHSHE:2015:3780, r.o. 3.12 .

45. Enigszins onzorgvuldig voegt de rechtbank daaraan toe dat, 'ook als LaBell is opgericht zodat InfoRhei en Horsten hun winsten niet langer zouden hoeven delen, daaruit geen opzet volgt, noch dat InfoRhei daardoor is benadeeld' (curs. TK \& CdK); zie r.o. 3.15 van het vonnis, vermeld in Hof Den Bosch 29 september 2015, ECLI:NL:GHSHE:2015:3780, r.o. 3.8. In zoverre vindt vernietiging plaats, hoewel het hof er in r.o. 3.9 ook reeds van uit lijkt te gaan dat de rechtbank onder ogen heeft gezien dat het overhevelen van de onderneming van Mulix naar LaBell de aandelen van InfoRhei waardeloos heeft gemaakt.

46. Rb. Zeeland-West-Brabant, vermeld in Hof Den Bosch 29 september 2015, ECLI:NL:GHSHE:2015:3780, r.o. 3.8-3.9. 


\section{Maandblad}

Ondernemingsrecht

Het Hof Den Bosch kwam in hoger beroep tot een ander oordeel. Dat InfoRhei schade heeft geleden, staat voor het Hof Den Bosch, anders dan bij de rechtbank het geval was (zie voetnoot 45 ), wel vast. Deze schade is, gelet op het faillissement van Mulix en Mulix Holding, definitief. Ook het hof hanteert voor toewijzing van de vordering omtrent afgeleide schade als eis dat van de kant van Horsten sprake dient te zijn van schending van een specifieke zorgvuldigheidsnorm, hetgeen bijvoorbeeld naar voren kan komen in de opzet om InfoRhei als aandeelhouder te benadelen. Anders dan in Kessock/SFT Bank lijkt in het onderhavige geval geen sprake te zijn van bij InfoRhei levende gerechtvaardigde verwachtingen - althans niet in dezelfde mate - waarmee Horsten in strijd zou hebben kunnen handelen. Van een statutaire of contractuele bepaling die specifiek beoogde InfoRhei te beschermen, blijkt in verschillende instanties niet. Hoewel schending van een specifieke zorgvuldigheidsverplichting zich wel degelijk (vergelijk par. 5.1) buiten het opzetaspect kan manifesteren, komt in dergelijke gevallen - en dus ook voor het Hof Den Bosch - de (zware $\left.{ }^{47}\right)$ bewijslast dat een specifieke zorgvuldigheidsnorm is geschonden in de vorm van opzet naar voren. Hierop richt zich dan ook het betoog van partijen. Volgens InfoRhei kan het, gezien de slechte onderlinge verhoudingen, niet anders zijn dan dat bij Horsten de opzet heeft bestaan een specifiek jegens InfoRhei geldende zorgvuldigheidsverplichting te schenden. Met het hof achten wij een dergelijk betoog onvoldoende. Opnieuw heeft InfoRhei voorgesteld getuigen, die zouden kunnen verklaren omtrent de bij Horsten aanwezige opzet, te laten horen. Het hof stelt ter zake dat InfoRhei weliswaar heeft voldaan aan haar stelplicht, maar (nog) niet is geslaagd in het leveren van bewijs. Het bewijsaanbod van InfoRhei wordt derhalve toegestaan. ${ }^{48}$

\subsection{Een blik vooruit}

In de aanpak van het hof om niet aan het bewijsaanbod van InfoRhei voorbij te gaan, kunnen wij ons, gelet op artikel 166 en $353 \mathrm{Rv}$, beter vinden. Het betreft immers beoordeling in laatste feitelijke (tweede) instantie en de getuigenis kan voor de uitkomst van de zaak cruciaal zijn. ${ }^{49}$ Tegelijkertijd, mede gelet op de ervaringen in eerste aanleg, doemt de vraag op waarom InfoRhei de getuigenverklaringen niet eerder heeft ingebracht. Dat doet ons ook enigszins twijfelen aan de inhoud van hetgeen de getuigen zullen gaan verklaren. InfoRhei stelt daaromtrent dat de getuigen kunnen verklaren dat Horsten InfoRhei 'kapot zou maken' - opzet lijkt dan inderdaad aanwezig te zijn geweest. Het gaat - voor InfoRhei - echter reeds mis op het moment dat getuigen zouden verklaren dat Horsten beoogde Mulix kapot te maken. Het betoog dat Horsten met het oprichten van LaBell beoogde werknemers van Mulix hun baan te laten houden, lijkt ons evenmin onaan- nemelijk. In die benadering is het faillissement van Mulix meer gevolgschade dan het resultaat van opzet. Mochten de getuigen desondanks een voor InfoRhei gunstige verklaring kunnen afleggen, dan is voor artikel 166 en $353 \mathrm{Rv}$ nog van belang in hoeverre daaraan gewicht moet worden toegekend. Zulks is, gelet op de vrije waardering van bewijs, onder andere afhankelijk van de vraag onder welke omstandigheden Horsten de bewering heeft gedaan. Aldus is de stand van zaken op dit moment binair te noemen: óf het getuigenbewijs maakt opzet aan de kant van Horsten niet aannemelijk - in dat geval zijn de kansen voor laatstgenoemde voorlopig verkeken - óf het getuigenbewijs wijst juist wel in die richting, in welk geval de vraag is welk gewicht daaraan toekomt. Wij wijzen er nog op dat, ingeval die vordering tot vergoeding van via LaBell omgeleide winsten toegewezen mocht worden, een schadestaatprocedure (art. $612 \mathrm{Rv}$ ) voor de hand lijkt te liggen. Alsdan zijn InfoRhei en Mulix ook na de einduitspraak van het Hof Den Bosch nog niet van elkaar verlost, nog afgezien van een eventuele gang naar de Hoge Raad. Wij wachten hoe dan ook in spanning af.

\section{Afronding}

In de tot nu toe gewezen uitspraken in de geschillen tussen (materieel) Van Lakwijk c.s. en Horsten komen verschillende leerstukken van Nederlands vennootschapsrecht aan bod. Wat deze casus duidelijk maakt, is dat niet alleen liefdes in het ondernemingsrecht kunnen falen, maar ook scheidingen na gefaalde liefdes. De gewenste scheiding kon in ieder geval niet via de enquêteprocedure ten overstaan van de OK worden bereikt, zelfs niet nadat de OK een onderzoeker en vervolgens een bindend adviseur had aangesteld. Dat partijen er niet voor hebben gekozen om de ontvlechting van hun onderneming via de band van de wettelijke geschillenregeling - zelfs niet in kort geding - te (laten) effectueren, is op zijn beurt veelzeggend over de al dan niet gepercipieerde obstakels waarmee de geschillenregeling indertijd gepaard ging, en ten dele nog steeds gepaard gaat. Ondertussen leidde de 'fall-out' van de gefaalde scheiding tot nieuwe problemen en werd een van de voormalige vennootschapsrechtelijke echtelieden in een poging tot bescherming van de eigen positie geconfronteerd met hobbels uit de leerstukken van vennootschappelijke concurrentie (corporate opportunity) en afgeleide schade. De procedures tussen Van Lakwijk c.s. en Horsten, hoe interessant ook vanuit ondernemingsrechtelijk perspectief, leveren al met al geen fraai beeld op. Het valt te hopen dat door de einduitspraak van het Hof Den Bosch partijen uit hun lijden worden verlost, hoewel niet uit te sluiten valt dat ook dat arrest geen eindstation zal blijken.

\footnotetext{
47. S. Schmeetz, Enkele aspecten van de (on)mogelijkheid tot het vorderen van 'afgeleide schade', V\&O 2010, afl. 11, p. 206-210.

48. Hof Den Bosch 29 september 2015, ECLI:NL:GHSHE:2015:3780, r.o. 3.13.4-3.13.6.

49. Vgl. over het passeren van getuigenbewijs in hoger beroep HR 31 oktober 2014, ECLI:NL:HR:2014:3075, NJ 2014/475.
} 